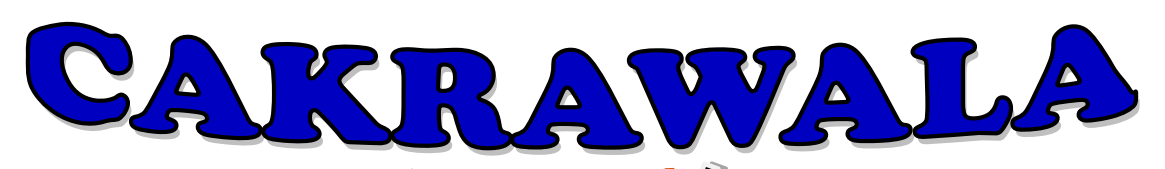

Management Business Journal [CM:-BJ] Volume 1 Nomor 1 Tahun 2018

\title{
EVENT CANDIPURO CULTURE FESTIVAL : STRATEGI PROMOSI PARIWISATA BERBASIS BUDAYA
}

\author{
Nawangsih \\ STIE Widya Gama Lumajang \\ Correspondence email: lovinawang@gmail.com
}

Page | - 1 -

\begin{abstract}
ABSTRAK
Potensi wisata dan kearifan lokal yang unik dan menarik yang dimiliki daerah selama ini masih kurang dipromosikan keberadaannya. Event Candipuro Culture Festival dapat dijadikan peluang dan eksplorasi nilai lebih wisata budaya suatu daerah untuk dipromosikan sebagai destinasi wisata potensial wisatawan. Tujuan penelitian untuk mengetahui strategi promosi pariwisata yang dilakukan dalam mempromosikan dan atraksi budaya yang ditampilkan dalam Event Candipuro Culture Festival.

Penelitian menggunakan metode deskriptif kualitatif. Teknik pengumpulan data melalui wawancara, observasi dan dokumentasi. Tahapan kegiatan analisa data: pengumpulan data, reduksi data, penyajian data dan penarikan kesimpulan.

Hasil penelitian bahwa Strategi promosi yang digunakan pada Event Candipuro Culture Festival dilakukan menggunakan media online dan offline untuk meningkatkan jumlah kunjungan wisatawan. Atraksi budaya yang ditampilkan pada Event Candipuro Culture Festival berbasis budaya, yaitu dalam bentuk kesenian tradisional dan kearifan lokal penduduk setempat, akan tetapi ada unsur budaya yang maknanya sudah mulai bergeser, sehingga perlu perhatian lebih. Pentingnya pelestarian budaya dari generasi ke generasi agar tidak kehilangan makna.
\end{abstract}

\section{ABSTRACT}

The unique and interesting tourism potential and local wisdom that the region has had so far is still not being promoted. The Candipuro Culture Festival event can become an opportunity and explore the value of cultural tourism in a region to be promoted as a potential tourist destination for tourists. The purpose of the study was to find out the tourism promotion strategies carried out in promoting and cultural attractions displayed in the Candipuro Culture Festival Event

The study used a qualitative descriptive method. collecting data technique are interviews, observation and documentation. step of data analysis activities: data collection, data reduction, data presentation and conclusion drawing.

The results that the promotion strategy used in the Candipuro Culture Festival Event was conducted using online and offline media to increase the number of tourist visits. Cultural attractions displayed at the Culture-based Candipuro Culture Festival Event, namely in the form of traditional arts and local wisdom of local residents, but there are cultural elements whose meaning has begun to shift, so more attention is needed. The importance of cultural preservation from generation to generation so as not to lose meaning.

Keywords : Candipuro, Promotion, Tourism, Culture. 


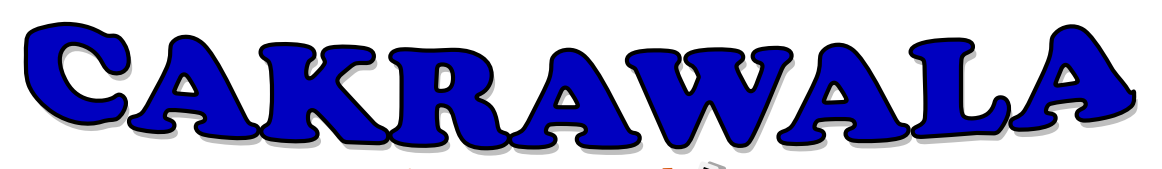

\section{Management Business Journal [CM:-BJ] Volume 1 Nomor 1 Tahun 2018}

\section{PENDAHULUAN}

UU No. 10 tahun 2009 mengenai kepariwisataan mengindikasikan wisata adalah kegiatan perjalanan yang dilakukan oleh seseorang atau sekelompok orang. Walaupun kebutuhan berwisata bukan merupakan kebutuhan primer manusia, Page |-2 nampaknya hal ini tidak menyurutkan kedudukan kontribusi sektor pariwisata dalam peningkatan devisa negara. Rai Utama (2017:6), pembangunan pariwisata mampu menggerakkan aktifitas bisnis, manfaat sosial dan ekonomi yang cukup signifikan. Persaingan dalam industri pariwisata membawa dampak terhadap tuntutan agar sebuah destinasi wisata memiliki keunikan dan daya tarik khusus, sehingga mampu menarik minat berkunjung sekaligus mampu memenangkan persaingan.

Salah satu bentuk kegiatan pariwisata dengan keunika dan daya tarik khusus yang dimiliki adalah wisata budaya. Konsep wisata budaya mengedepankan pada sisi budaya sebagai unsur utama bersinergi dengan kearifan lokal masyarakat. Penguatan budaya lokal seperti kesenian tradisional melalui media event budaya, selain sebagai wujud pelestarian budaya sekaligus sebagai edukasi budaya agar bisa berkelanjutan antar generasi. Nilai budaya daerah dengan keunikan dan ciri khasnya masing-masing menjadi keunggulan kompetitif pariwisata berbasis budaya, sehingga potensi budaya yang dimiliki akan lebih maksimal hasilnya dengan didukung sarana promosi yang tepat. Promosi menurut Middleton (1994) dalam Rai Utama (2017:32) adalah deskrispsi kegiatan komunikasi menggunakan media untuk mempengaruhi orang lain. Berdasarkan sudut pandang promosi konsumen atau wisatawan adalah obyek yang dituju, karena mereka memiliki kebutuhan yang harus dipengaruhi. Saat ini kegiatan promosi berbasis tekhnologi menjadi salah satu pilihan dengan pertimbangan efisiensi, karena pemanfaatan tekhnologi daalam kegiatan promosi yang dilakukan memberikan dampak yang cukup besar bagi keberhasilan kegiatan promosi yang dilakukan. 


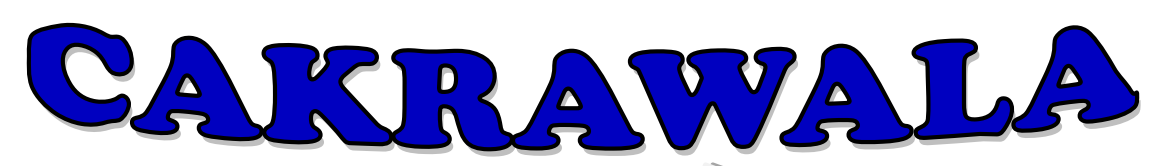

\section{Management Business Journal [CM:B. J] Volume 1 Nomor 1 Tahun 2018}

Kajian penelitian terkait dengan strategi promosi pariwisata berbasis budaya menarik untuk diteliti, dan hal semacam ini pernah dilakukan oleh beberapa penelitian terdahulu, antara lain : Mia Rachmayanti dan Nofharina, tahun 2018, tentang Analisis Strategi Promosi Dalam Pengembangan Pariwisata, (Studi Kasus Page |-3 pada Pariwisata Kabupaten Purwakarta), hasil penelitian menunjukkan bahwa Kabupaten Purwakarta menjalankan kegiatan strategi promosi dilakukan dengan menerapkan tahapan kegiatan promosi dengan baik dan benar dan Penelitian dari Yugih Setyanto dan Septia Winduwati, tahun 2017, tentang Diseminasi Informasi Terkait Pariwisata Berwawasan Lingkungan dan Budaya Guna Meningkatkan Daya Tarik Wisatawan (Studi pada Dinas Pariwisata Provinsi Nusa Tenggara Barat), hasil penelitian menunjukkan bahwa masing-masing pemerintah daerah memiliki otoritas dalam mengembangkan serta mempromosikan potensi wisata yang ada, sehingga potensi wisata daerah yakni pariwisata yang berwawasan lingkungan dan budaya bisa secara maksimal dikenal oleh masyarakat dan meningkatkan daya tarik wisatawan, khususnya turis dalam dan luar negeri. Sedangkan pada penelitian yang dilakukan sekarang berkaitan dengan peran event budaya sebagai media promosi pariwisata karena keunikan dan nilai kearifan lokal yang terkandung di dalamnya sebagai daya tarik wisata.

Promosi menurut Fandi Tjiptono (2002: 217) adalah salah satu bentuk komunikasi pemasaran yaitu aktifitas pemasaran yang berusaha menyebarkan informasi, mempengaruhi/membujuk, dan/atau mengingatkan pasar sasaran atas perusahaan dan produknya agar bersedia menerima, membeli dan loyal pada produk yang ditawarkan perusahaan yang bersangkutan. Sedangkan menurut Yoeti (2008:141) dalam Suryadana dan Oktavia (2015) adalah untuk memberitahukan, membujuk atau mengingatkan lebih khusus lagi.

Bauran promosi yang digunakan dalam kegiatan pariwisata menurut Suryadana dan Oktarina (2015:158) terdiri dari advertising, atau periklanan sebagai salah satu bentuk komunikasi impersonal yang digunakan perusahaan barang 


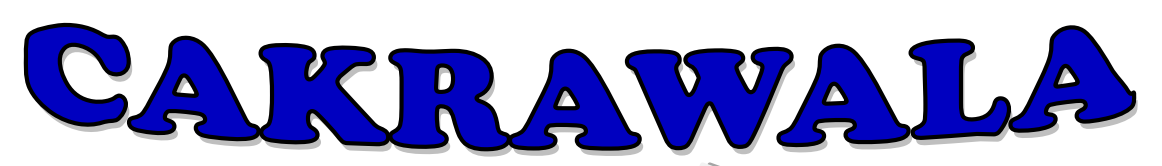

\section{Management Business Journal [CM:-BJ] Volume 1 Nomor 1 Tahun 2018}

maupun jasa, sales promotion yaitu kegiatan pemasaran selain periklanan yang mendorong efektifitas pembelian konsumen dan pedagang perantara dengan menggunakan alat-alat promosi yaitu brosur, pameran dan demonstrasi, personal selling atau penjualan tatap muka merupakan aktifitas komunikasi antar produsen Page |-4 yang diwakili oleh tenaga penjual, dengan konsumen potensial yang melibatkan pikiran dan emosi, serta berhadapan langsung dengan pembeli, serta public relation yaitu bertanggung jawab dalam menentukan dan mempertahankan komunikasi 2 arah secara terbuka dengan semua lapisan masyarakat serta menciptakan opini masyarakat yang baik tentang produk pariwisata yang ditawarkan oleh perusahaan.

Pada Event Candipuro Culture Festival maka tujuan kegiatan promosi yang dilakukan adalah untuk menginformasikan terkait adanya Event Candipuro Culture Festival sekaligus untuk mempengaruhi dan membujuk wisatawan agar tertarik berkunjung ke acara tersebut, untuk menyaksikan atraksi wisata budaya dan kearifan lokal masyarakat. Media promosi yang digunakan untuk mempromosikan Event Candipuro Culture Festival adalah menggunakan publisitas baik melalui media cetak maupun elektronik, agar kegiatan yang diselenggarakan dapat diketahui masyarakat secara luas, bukan hanya untuk masyarakat lokal saja. Media publikasi yang digunakan cukup beragam mulai dari media online yaitu : facebook, instagram dan whats up, maupun melalui brosur, iklan dan menggunakan media massa lokal yaitu tabloid dan surat kabar daerah. Event Candipuro Culture Festifal juga mendapatkan apresiasi positif dari beberapa media nasional yang juga ikut meliput keberadaan acara tersebut, sebagai bentuk nilai budaya dan kearifan lokal daerah.

Kegiatan promosi pariwisata berbasis budaya dilaksanakan di Kecamatan Candipuro, Kabupaten Lumajang. Pariwisata berbasis budaya menjadi tema utama Event Candipuro Culture Festival yang diselenggarakan di Kecamatan Candipuro, Kabupaten Lumajang, Jawa Timur. Kecamatan Candipuro berada sekitar $30 \mathrm{~km}$ sebelah barat dari Kabupaten Lumajang. Daerah tersebut memiliki potensi pariwisata yang cukup besar, bukan hanya dari segi daya tarik alam yang dimiliki, 


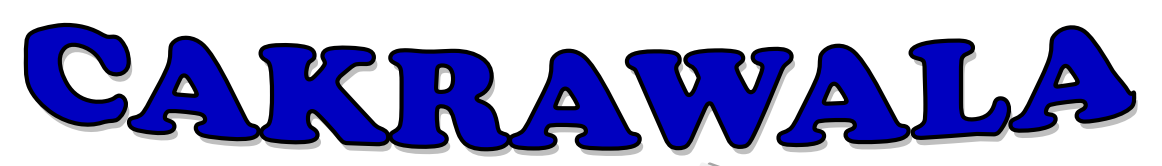

\section{Management Business Journal [CM:-BJ] Volume 1 Nomor 1 Tahun 2018}

melainkan juga budaya dan kearifan lokal masyarakat. Beberapa desa yang ada di Kecamatan Candipuro memiliki potensi wisata budaya, diantaranya : Desa Sumbermujur, Desa Tambahrejo dan Desa Penanggal. Berdasarkan Undang-Undang No.6 Tahun 2014 tentang desa, mengisyaratkan bahwa pendanaan tingkat desa Page |-5untuk mendorong pembangunan desa salah satunya dari sektor pariwisata.

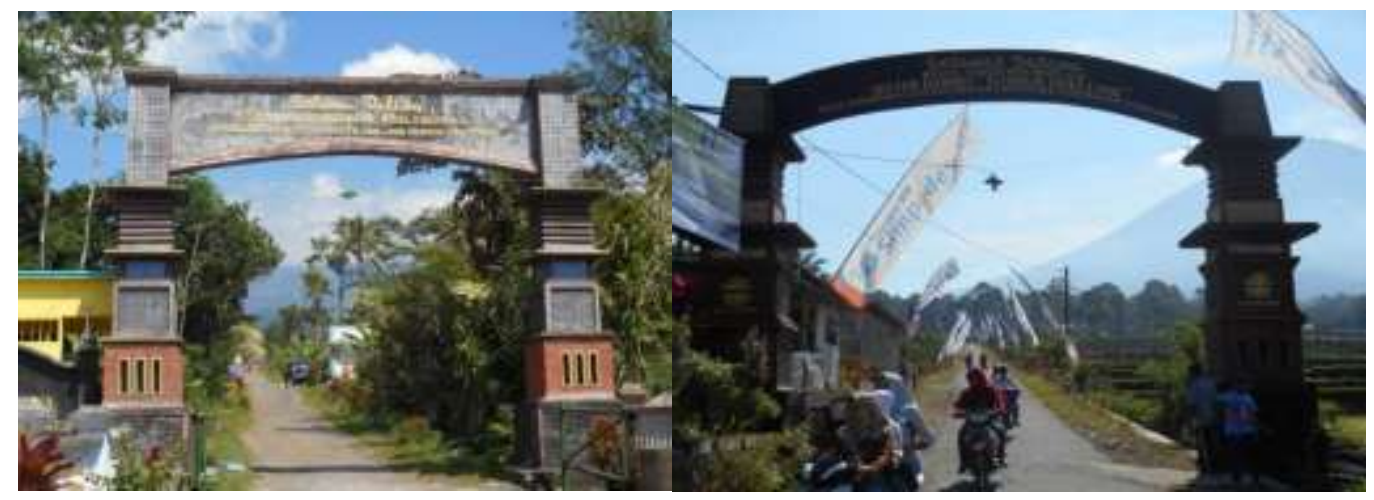

Gambar 1.

\section{Situasi dan Kondisi Desa Sumbermujur, Kecamatan Candipuro, Kabupaten Lumajang}

Salah satu bentuk optimalisasi sektor pariwisata yang ada di desa, dilakukan melalui Event Candipuro Culture Festival yang diselenggarakan dengan menjalin sinergi dari ke 3 desa tersebut, untuk bersama-sama menggalakkan potensi pariwisata khususnya wisata budaya, mengingat potensi modernisasi sudah mulai masuk ke wilayah pedesaan termasuk dari segi budaya, sehingga sebagai bentuk antisipasi sekaligus tindakan preventif masuknya budaya yang negatif, maka Event Candipuro Culture Festival tersebut diadakan. Kegiatan promosi Event Candipuro Culture Festival gencar dilakukan dengan tujuan agar banyak wisatawan yang tertarik berkunjung ke desa tersebut, bukan hanya untuk menikmati event budaya dan kearifan lokal masyarakat yang ditampilkan. 


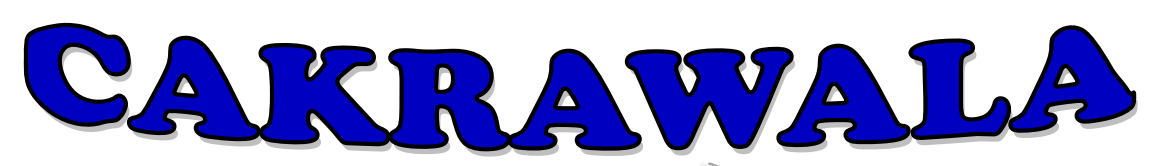

\section{Management Business Journal [CM:-BJ] Volume 1 Nomor 1 Tahun 2018}

Tujuan Penelitian yang dilakukan adalah : untuk mengetahui strategi promosi pariwisata yang dilakukan dalam mempromosikan Event Candipuro Culture Festival dan untuk mengetahui atraksi budaya yang ditampilkan dalam Event Candipuro Culture Festival.

Penggunaan strategi promosi yang tepat besar peranannya dalam mendukung keberhasilan kegiatan promosi yang dilakukan. Strategi menurut Zaki dan Priyo (2015:14) yaitu pola pengaturan kebijakan dan rencana untuk mencapai tujuan yang diinginkan, sehingga strategi promosi dapat di artikan sebagai suatu perencanaan atau pola yang diatur dan direncanakan untuk menyampaikan suatu informasi mengenai suatu produk atau jasa kepada target sasaran.

Penelitian tentang strategi promosi pariwisata berbasis budaya ini dilakukan dengan harapan agar, kegiatan promosi yang dilakukan bisa tepat sasaran dan tujuan utama untuk pelestarian dan edukasi budaya kepada masyarakat bisa tercapai.

\section{METODE PENELITIAN}

Rancangan Penelitian

Rancangan penelitian yang dilakukan adalah penelitian kualitatif deskriptif, yang digunakan untuk mendeskripsikan dan menjelaskan tentang strategi promosi pariwisata yang dilakukan dalam mempromosikan Event Candipuro Culture Festival dan atraksi budaya yang ditampilkan dalam Event Candipuro Culture Festival.

\section{Sasaran penelitian}

Sasaran atau obyek penelitian berada di Desa Sumbermujur, Desa Tambahrejo dan Desa Penanggal. Kecamatan Candipuro, Kabupaten Lumajang. Ke 3 (tiga) desa tersebut dipilih berdasarkan pertimbangan : event wisata budaya yang dilaksanakan di desa tersebut, menarik dan memiliki keunikan tertentu yang berbeda dengan daerah lain, misalnya : tradisi yang ditampilan berbasis budaya dalam hal ini kesenian dan kearifan lokal, selain unsur budaya masyarakat di desa tersebut juga 


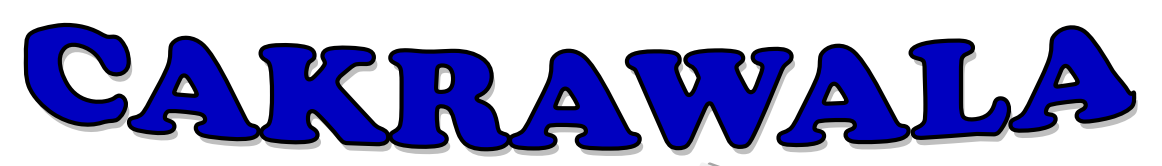

\section{Management Business Journal [CM:-BJ] Volume 1 Nomor 1 Tahun 2018}

memiliki nilai kearifan lokal yang tetap dilestarikan dan keunikan dari segi wisata alam yang dimiliki.

\section{Narasumber/Informan Penelitian}

Adapun narasumber/informan penelitian terdiri dari : Kepala Desa, peran dan Page | - 7 kapasitasnya sebagai pemimpin tertinggi di desa yang mengetahui secara spesifik terkait dengan pariwisata dan nilai kearifan lokal desa, sebagai penanggung jawab pelaksanaan kegiatan sekaligus ikut berpartisipasi dalam bentuk tarian "Semar Mbangun Kayangan", Panitia penyelenggara peran dan kapasitasnya sebagai pihak penyelenggara Event Candipuro Culture Festival, sebagai pusat informasi kegiatan wisata budaya yang diadakan, sekaligus sebagai pihak yang ikut berpartisipasi dalam kegiatan pawai dalam bentuk tarian kolosal "Semar Mbangun Kayangan", Dinas Kebudayaan dan Pariwisata Kabupaten Lumajang kapasitasnya sebagai perwakilan dari pemerintah yang memberikan dukungan terhadap perkembangan pariwisata di Kabupaten Lumajang khususnya pariwisata berbasis budaya, penggiat seni kapasitasnya sebagai pelaku utama seni baik seni tradisional maupun kontemporer sebagau wujud pelestarian budaya dan nilai kearifan lokal masyarakat, masyarakat Desa Sumbermujur, Desa Tambahrejo dan Desa Penanggal kapasitasnya sebagai penduduk asli yang memahami secara lebih detail terkait dengan budaya dan nilai kearifan lokal yang sudah menjadi tradisi secara turun temurun yang tetap dilestarikan di daerah tersebut dan wisatawan kapasitasnya sebagai pihak eksternal baik wisatawan lokal maupun wisatawan asing yang datang berkunjung untuk menyaksikan sekaligus ikut berpartisipasi dalam Event Candipuro Culture Festival .

\section{Teknik Pengumpulan Data}

Teknik pengumpulan data pada penelitian yang dilakukan menggunakan wawancara, observasi dan dokumentasi (Bungin, 2007:108). Metode pengumpulan data pimer menggunakan wawancara mendalam (In-depth Interview). Sedangkan metode pengumpulan data sekunder dilakukan dengan studi pustaka melalui data yang didapatkan dari sumber literatur kepustakaan berupa buku-buku, surat kabar, 


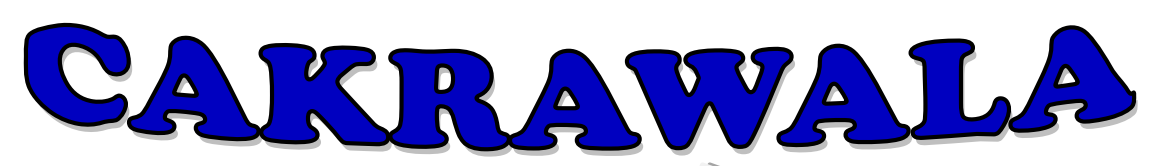

\section{Management Business Journal [CM:-BJ] Volume 1 Nomor 1 Tahun 2018}

artikel/tulisan pada media massa dan internet, foto, dokumen organisasi, website organisasi, serta hasil penelitian yang menjadi referensi dan yang berhubungan dan obervasi/pengamatan hasil penelitian yang ada dilapangan.

Teknik Analisa Data

Tahapan kegiatan analisa data, menurut Milles dan Huberman (1994) disebut dengan Interactive Model, yang meliputi : pengumpulan data, reduksi data, penyajian data dan penarikan kesimpulan, (Sutopo, 2002:96).

\section{HASIL PENELITIAN}

\section{Strategi Promosi Pariwisata yang Dilakukan dalam Mempromosikan Event Candipuro Culture Festifal}

Penentuan strategi promosi yang tepat besar peranannya dalam keberhasilan kegiatan promosi yang dilakukan. Event Candipuro Culture Festival yang diselenggarakan di Kecamatan Candipuro, pada tanggal 11, 12 , dan 13 September 2018, dipromosikan baik melalui media cetak maupun media eletronik melalui kerja sama dengan berbagai pihak yang terlibat di dalamnya seperti yang diungkapkan oleh beberapa informan, sebagai berikut :

“...Event Candipuro Culture Festival rencananya akan dijadikan agenda rutin, untuk mempromosikan wisata budaya, tradisi, dan kesenian khas daerah, dengan memanfaatkan media cetak maupun media elektronik baik lokal maupun nasional serta bekerja sama dengan dinas yang terkait, misalnya Dinas Kebudayaan dan Pariwisata, untuk menarik minat wisatawan berkunjung ke destinasi wisata tersebut..".

Kegiatan promosi dengan memanfaatkan berbagai media baik media cetak maupun elektronik sekaligus sebagai bentuk kegiatan bauran promosi terutama dari sisi publisitas, yang dilaksanakan agar mampu menjangkau masyarakat yang lebih luas. Publisitas melalui media sosial salah satunya memegang peranan yang cukup besar dari keberhasilan Event Candipuro Culture Festival yang diselenggarakan, 


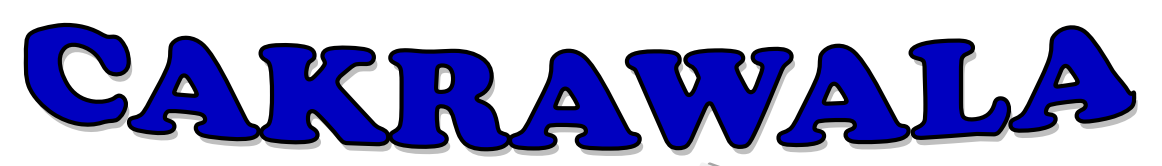

\section{Management Business Journal [C,}

mengingat dari beberapa informan penelitian khususnya wisatawan menyebutkan bahwa mereka mengetahui acara ini melalui media sosial, bentuk promosi cukup unik dan menarik dengan mengangkat tema budaya, dan kearifan lokal dengan keunikan dan folosofi luhur, menjadi daya tarik tersendiri bagi wisatawan yang Page |-9berkunjung ke Event Candipuro Culture Festival Tersebut, karena berbeda dengan dengan jenis atraksi budaya yang lain. Sehingga kegiatan promosi melalui publikasi yang dilakukan akan menciptakan daya tarik dan opini publik yang bagus terhadap potensi pariwisata daerah. Adapun hasil dokumentasi penelitian:

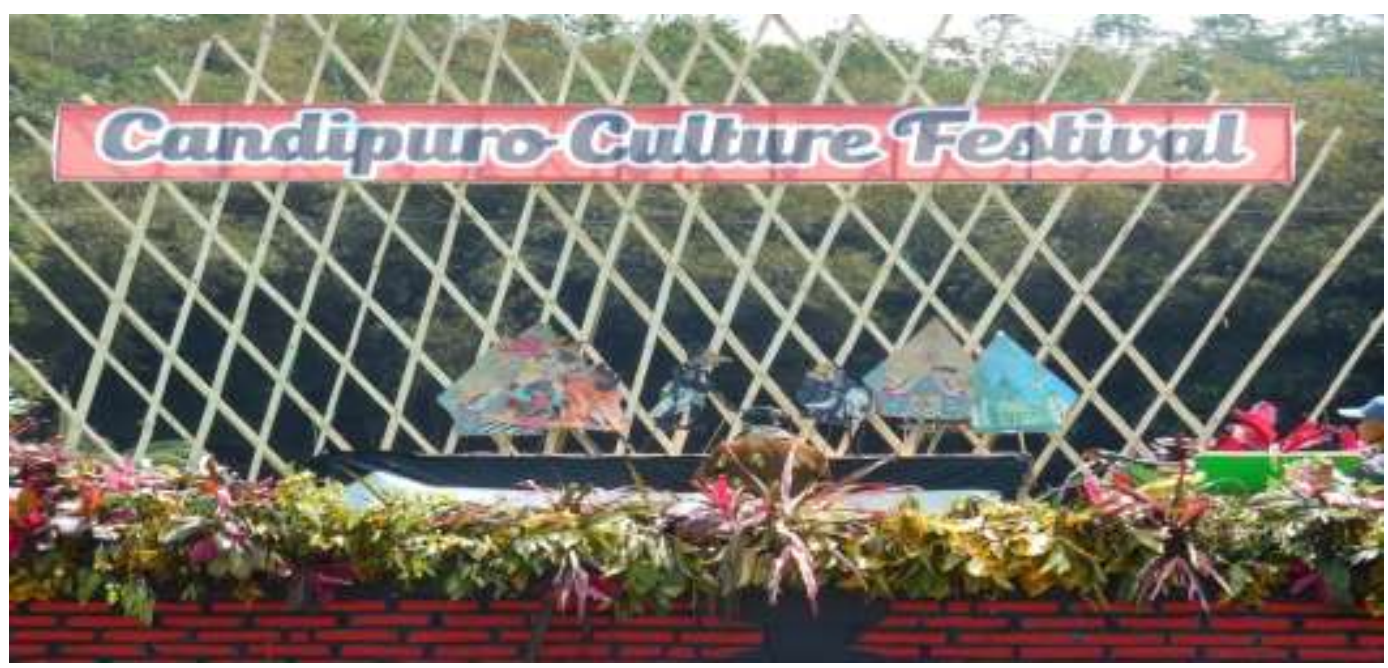

Gambar 2.

\section{Event Candipuro Culture Festival}

Pendapat lain tentang promosi wisata dikemukakan oleh informan sebagai berikut :

“...Acara grebeg suro yang diselenggarakan di Desa Sumbermujur, sebagai salah satu rangkaian wisata budaya, dikemas sebagai bentuk pelestarian tradisi dan kearifan lokal masyarakat yang dilaksanakan secara turun temurun dalam event Candipuro Culture Festival, turut diliput oleh beberapa stasiun televisi nasional. Misalnya TV One, JTV, Indosiar dan juga beberapa media cetak lokal seperti Radar Lumajang dan Mahameru serta melalui media sosial..". 


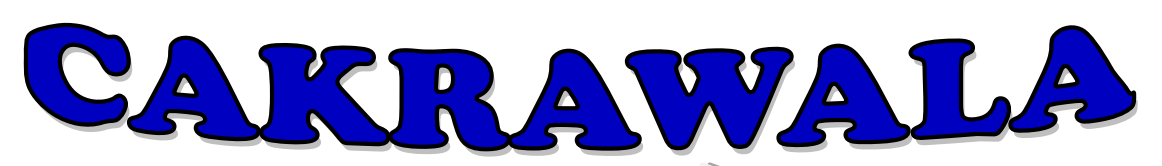

\section{Management Business Journal [C:M:BJ] Volume 1 Nomor 1 Tahun 2018}

Pendapat lain tentang kegiatan promosi wisata juga dikemukakan oleh informan, sebagai berikut :

“..Saya mengetahui Event Candipuro Culture Festival ini, melalui media sosial facebook dan instagram, sepertinya ini event besar yang baru pertama kalinya Page |-10diadakan selama 3 (tiga) hari berturut-turut di 3 (tiga) desa, menarik sekali, apalagi berkaitan dengan budaya, pasti banyak yang tertarik,unik dan sarat makna dan filosofi luhur budaya dan tradisi.."

Pendapat lain terkait promosi yang dilakukan dalam Event Candipuro Culture Festival dikemukakan oleh informan sebagai berikut :

“...Jumlah pengunjung yang datang cukup banyak, kegiatan promosinya sepertinya berhasil, karena meskipun ini wisata budaya ternyata jumlah pengunjung yang datang cukup besar, antusiasme pengunjung juga tidak berkurang hingga acara berakhir, acaranya juga seru sekali, mampu dikemas dengan menarik, wisatawan juga bisa ikut terlibat dalam acara ceremonial tersebut.."

Pendapat lain terkait dengan kegiatan promosi disampaikan oleh informan sebagai berikut:

“..Promosinya sukses ini di grup lumajang satu di facebook banyak masyarakat yang menguploade berita tentang acara ini, banyak yang penasaran, karena atraksi budaya yang ditampilkan menarik dan beragam...".

Berdasarkan beberapa penjelasan informan tersebut di atas menunjukkan bahwa Event Candipuro Culture Festival, ternyata mampu digunakan sebagai sarana promosi wisata daerah khususnya wisata budaya, dimana pendapat dari beberapa informan menyebutkan bahwa strategi promosi yang dilakukan baik menggunakan media cetak, misalnya : harian radar lumajang, Mahameru dan media televisi : TV One, Indosiar dan JTV, serta media elektronik, misalnya facebook dan instagram, sangat berperan penting dalam mendukung keberhasilan kegiatan promosi yang dilakukan pada Event Candipuro Culture Festival. Diantara beberapa unsur bauran promosi yang ada yang paling besar peranannya dalam mendukung keberhasilan 


\section{CAKrawala}

\section{Management Business Journal [CM]-By]] Volume 1 Nomor 1 Tahun 2018}

kegiatan promosi yang dilakukan adalah dari segi iklan dan publikasi. Setyaningrum, Udaya, dkk (2015: 233) iklan sebagai bentuk kegiatan promosi atas gagasan, atau sponsor dalam bentuk media seperti : majalah, Koran, poster dan media televisi sedangkan publlikasi dilakukan dalam bentuk opini publik yang baik terhadap Page |-11kejadian yang ditampilkan.

\section{Atraksi Budaya yang Ditampilkan dalam Event Candipuro Culture Festifal.}

Atraksi budaya yang ditampilkan pada Event Candipuro Culture Festival, diselenggarakan selama 3 hari mulai dari tanggal 11, 12 dan 13 September 2018. Kegiatan tersebut diadadkan di 3 Desa yang ada di Kecamatan Candipuro yaitu : Desa Sumbermujur, Desa Tambahrejo dan Desa Penanggal. Pendapat beberapa informan terkait dengan Event Candipuro Culture Festival dikemukakan oleh beberapa informan sebagai berikut :

Pendapat informan terkait dengan atraksi budaya yang diselenggarakan di Desa Sumbermujur, adalah sebagai berikut :

“...Acara grebeg suro ini diadaakan dalam rangka pelestarian budaya daerah sekaligus sebagai bentuk rasa syukur desa, dengan menggelar ceremonial pemendaman kepala sapi di lokasi kawasan wisata hutan bambu, Desa Sumbermujur. Acara ini rutin diselenggarakan setiap bulan suro, dan sudah menjadi tradisi desa yang berlangsung secara turun temurun,.."
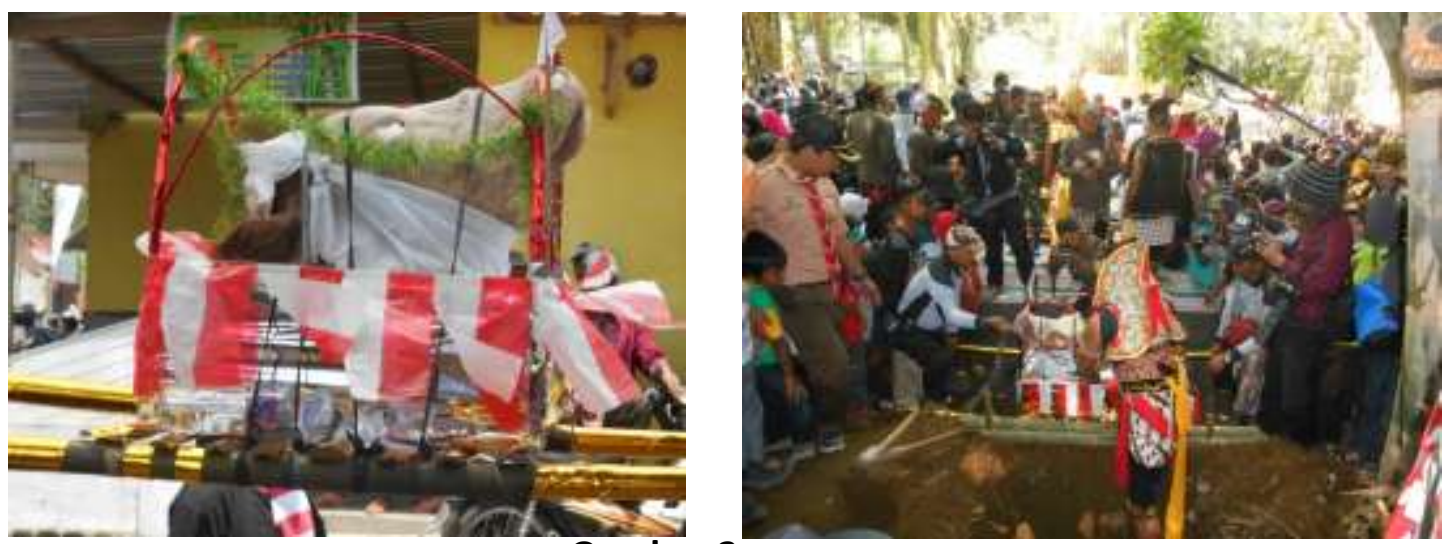

Gambar 3.

Acara Seremonial Pemendaman Kepala Sapi 


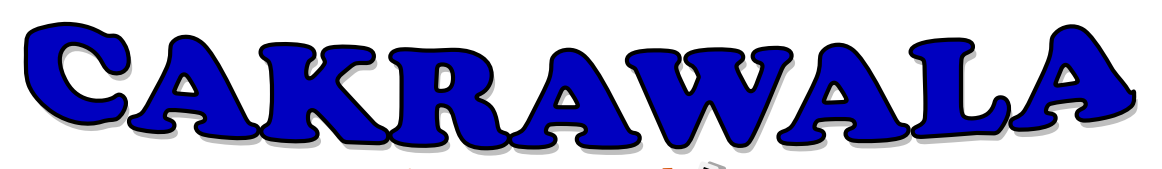

\section{Management Business Journal [C,}

Pendapat lain terkait dengan atraksi wisata budaya dalam bentuk kesenian tari tradisional khas daerah yaitu tari Gedhong Putri, disampaikan oleh informan berikut :

“..Kesenian tradisional dalam bentuk seni tari menjadi daya tarik wisata hutan Page | - 12 bambu. Tari yang ditampilkan secara kolosal, menceritakan tentang sejarah desa Sumbermujur yang dibawakan oleh para perangkat desa dan masyarakat pada event grebeg suro tersebut, memberikan daya tarik tersendiri bagi wisatawan, selain tari juga ada acara arak-arakan gunungan hasil pertanian, buah-buahan yang nantinya akan diperebutkan oleh masyarakat serta kenduri desa di lokasi wisata hutan bambu .."
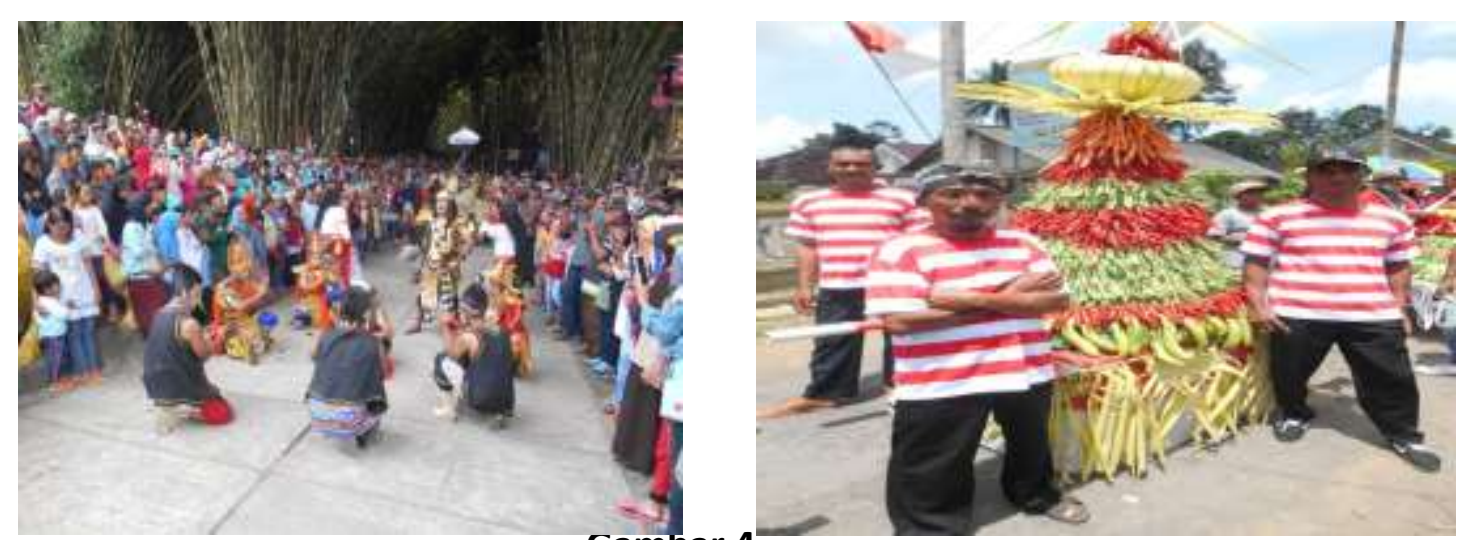

Gambar 4.

Atraksi Seni Tari dan Pawai Arak-Arakan Gunungan

Pendapat informan yang lain terkait dengan atraksi budaya yang diadakan di Desa Tambahrejo, adalah sebagai berikut :

“..Desa Tambahrejo terkenal dengan kesenian sampyongan ujung, semacam bentuk tarian tradisional dengan menggunakan media ujung yang terbuat dari rotan sebagai alat pukul, awalnya kesenian ini ditujukan sebagai bentuk upacara untuk mendatangkan hujan, akan tetapi sekarang sudah menjadi salah satu atraksi budaya yang bisa diikuti oleh semua kalangan,.." 


\section{Cakrawala}

\section{Management Business Journal [CM]-By]] Volume 1 Nomor 1 Tahun 2018}

Pendapat lainya terkait dengan atraksi smapyongan ujung dikemukakan oleh informan sebagai berikut :

"..Atraksi sampyongan ujung sepertinya sudah mengalami modernisasi, jika kegiatan ini termasuk budaya alangkah lebih baik jika kostum yang digunakan juga Page | - 13 menyesuaikan, sehingga kesan budaya masih kuat, irama music pengiring juga akan lebih menarik jika menggunakan musik tradisional, karena itu yang menjadi tarian sampyongan ujung menjadi menarik, jangan dirubah dengan menggunakan kostum modern dan lagu kekinian, karena kesan tradisional jadi hilang maknanya, sehingga bukan menjadi tradisional lagi,.."

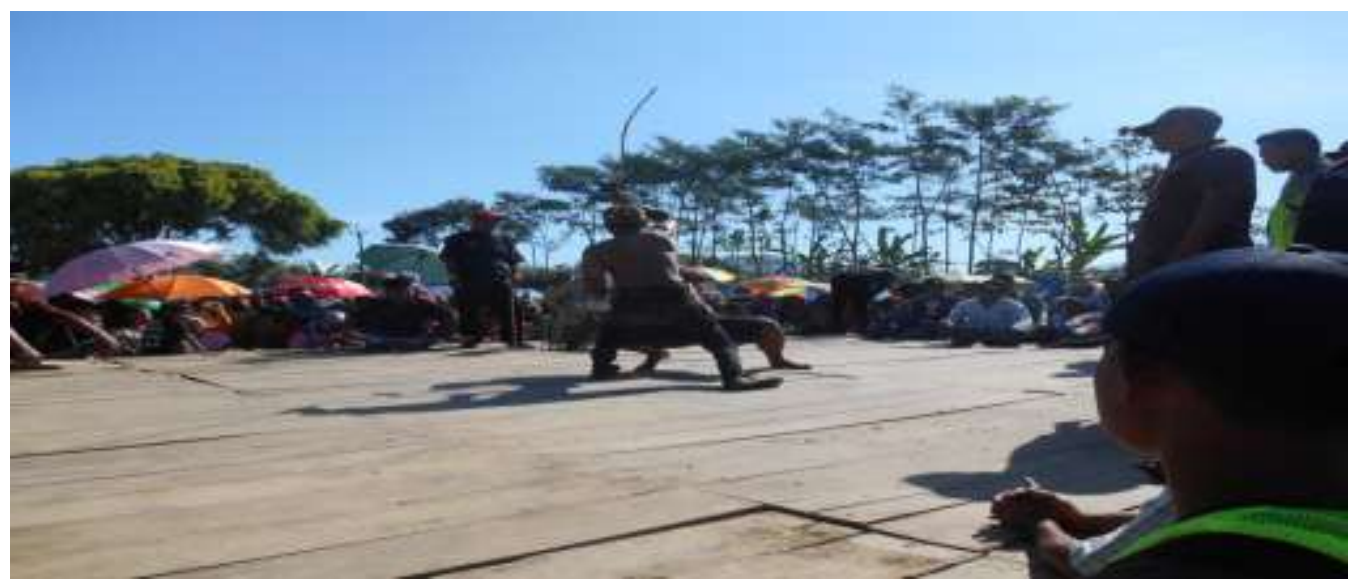

Gambar 5.

\section{Kesenian Sampyongan Ujung Desa Tambahrejo}

Pendapat lainnya terkait dengan atraksi budaya yang diselenggarakan di Desa Penanggal disampaikan oleh informan sebagai berikut :

“..Atraksi budaya yang ditampilkan di Desa Penanggal cukup beragam, mulai dari acara pawai kesenian khas daerah, arak-arakan gunungan, reog, wayang dan acara puncaknya ruwatan air di Pemandian Tirtosari View, menjadikan Event Candipuro Culture Festival menjadi lebih semarak dan ramai dengan antusiasme pengunjung.." 


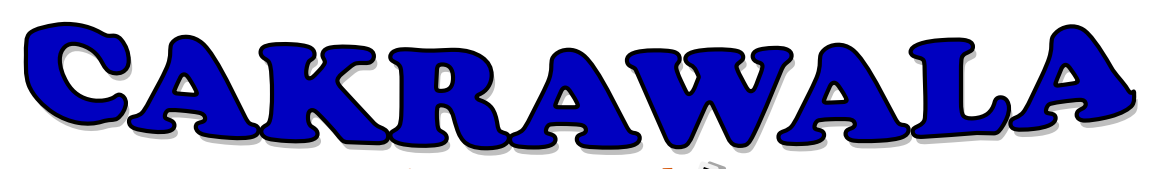

\section{Management Business Journal [CM:B, J Volume 1 Nomor 1 Tahun 2018}

Pendapat lain tentang Event Candipuro Culture Festival dikemukakan oleh informan sebagai berikut :

“..Ketika kita berkunjung ke Desa Penanggal maka kita akan mendapatkan paket lengkap, ada wisata budaya, wisata alam dan wisata ekonomi kreatif Page |-14gabungan dari ke 3 (tiga) desa sebelumnya, sehingga acara puncak ditempatkan di desa tersebut sangat cocok sekali, wisata ekonomi kreatif misalnya sengaja ditampilkan agar produk unggulan daerah bisa ikut dipromosikan sebagai oleh-oleh khas daerah bagi wisatawan yang datang, misalnya : kuliner khas daerah, makanan, cemilan, kerajinan dan beragam produk yang lain ...".

Adapun bentuk Wisata Budaya, Wisata Alam dan Industri Kreatif terlihat pada gambar dibawah ini:

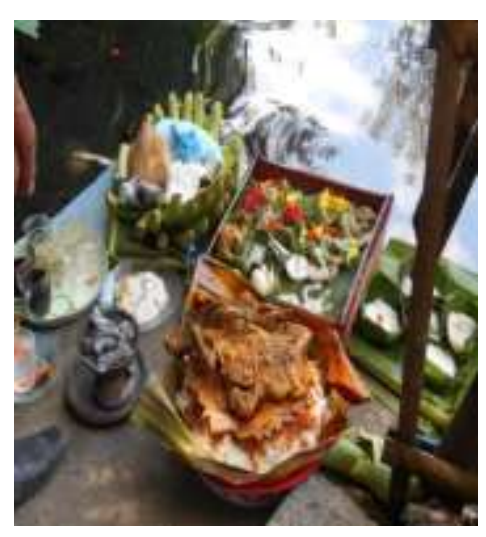

Wisata Budaya, Wisata Alam dan Industri Kreatif

Berdasarkan beberapa pendapat dari informan tersebut di atas menunjukkan bahwa atraksi budaya yang ditampilkan pada Event Candipuro Culture Festival, cukup beragam dengan sebagian besar tematik berbasis wisata budaya. Jenis kesenian yang ditampilkan antara lain : tari gedhong putri, tari reog, sampyongan ujung dan beberapa jenis tari lainnya, sedangkan kearifan lokal yang ditampilkan pada event tersebut antara lain : grebeg suro dan ruwatan air yang diselenggarakan di Desa Sumbermujur dan Desa Penanggal 


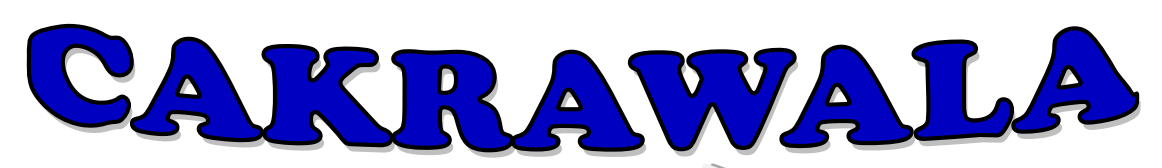

\section{Management Business Journal [CM:-BJ] Volume 1 Nomor 1 Tahun 2018}

Hasil temuan penelitian dilapangan menunjukkan bahwa kesenian tradisional sampyongan ujung, sudah mulai mengalami persegeseran bentuk dimana pada kegiatan tari yang ditampilkan sudah bukan murni mengangkat budaya melainkan sedah berakulturasi dengan modernitas. Misalnya : ketika tarian dipertunjukkan Page |-15para penari tidak semuanya menggunakan baju tradisional yang biasanya dikenakan pada tarian tradisional, musik pengiring kesenian tersebut juga merupakan kombinasi dengan menggunakan lagu daerah dan lagu dangdut atau lagu yang lagi trend pada zaman sekarang, sehingga unsur sakral dan kedaerahan pada seni tersebut mulai berkurang perannanya. Hal ini hendaknya mendapatkan perhatian lebih karena pada awalnya tarian yang sekarang sudah bergeser menjadi atraksi hiburan, sarat dengan makna filosofis yang luhur, yang harus dipertahankan dan dijaga kelestariannya

\section{PEMBAHASAN}

\section{Strategi Promosi Pariwisata yang Dilakukan dalam Mempromosikan Event Candipuro Culture Festival}

Strategi promosi yang dilakukan pada Event Candipuro Culture Festival dengan memanfaatkan beberapa media baik, cetak, elektronik maupun media online, terbukti cukup efektif dalam menarik minat kunjungan wisatawan di lokasi wisata tersebut. Para wisatawan datang berkunjung bukan hanya untuk berwisata melainkan juga mereka bisa sekaligus mendapatkan edukasi terkait budaya yang dimiliki oleh ke 3 (tiga) desa tersebut dengan ciri khas dan keunikan masing-masing. Sebagian besar wisatawan yang berkunjung mengetahui informasi terkait wisata tersebut dari media online baik itu facebook dan instagram terkait dengan promo wisata.

Hasil penelitian yang dilakukan ini mendukung terhadap hasil penelitian terdahulu yang dilakukan oleh Yugih Setyanto dan Septia Winduwati pada tahun 2017, dimana masing-masing pemerintah daerah memiliki otoritas dalam 


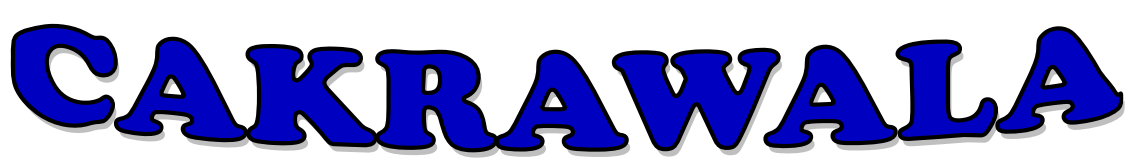

\section{Management Business Journal [CM:-BJ] Volume 1 Nomor 1 Tahun 2018}

mengembangkan serta mempromosikan potensi wisata yang ada, sehingga potensi wisata daerah yakni pariwisata budaya bisa secara maksimal dikenal oleh masyarakat dan meningkatkan daya tarik wisatawan, khususnya turis dalam dan luar negeri.

Kegiatan promosi melalui Event Candipuro Culture Festival sekaligus dicanangkan sebagai agenda wisata budaya yang secara rutin akan diadakan setiap tahun, sehingga bukan hanya potensi sumber daya alam saja yang menjadi keunikan dari ke 3 (tiga) desa ini, melainkan juga dari segi budaya dan kearifan lokal daerah. Kegiatan promosi yang dilakukan dengan menggunakan komponen bauran promosi, khususnya iklan dan publisitas untuk membantu keberhasilan kegiatan promosi wisata budaya yang dilakukan. Beberapa jenis media iklan yang digunakan, menurut Malau (2017:95) antara lain : televise, radio, majalah koran dan internet.

\section{Atraksi Budaya yang Ditampilkan dalam Event Candipuro Culture Festival.}

Atraksi budaya yang ditampilkan pada Event Candipuro Culture Festival cukup beragam, mulai dari kesenian daerah, kearifan lokal dan juga bazar produk ekonomi kreatif juga ikut ditampilkan pada event tersebut. Unsur kesenian daerah yang ditampilkan adalah bentuk seni tradisi yang berlangsung secara turun temurun, misalnya : kesenian tari, tari gedong putri, tari jaran slining, tari reog dan kesenian tari tradisional setempat. Salah satu atraksi seni tari yang ditampilkan yaitu tari “ Semar Mbangun Kayangan" ditampilkan oleh seluruh perangkat desa yang ada di Desa Sumbermujur, yang menceritakan tentang legenda punokawan dengan folosofi luhur yang dimilikinya. Selain atraksi kesenian juga ada bentuk nilai kearifan lokal misalnya acara seremonial pemendaman kepala sapi di lokasi mata air sumber deling di Desa Sumbermujur dan tradisi ruwatan air di Pemandian Tirtosari Desa Penanggal menjadi keunikan tersendiri dari potensi wisata di daerah tersebut.

Untuk melengkapi Event Candipuro Culture Festival juga ditampilkan stand produk unggulan dari masing-masing Desa dengan beragam potensi yang 


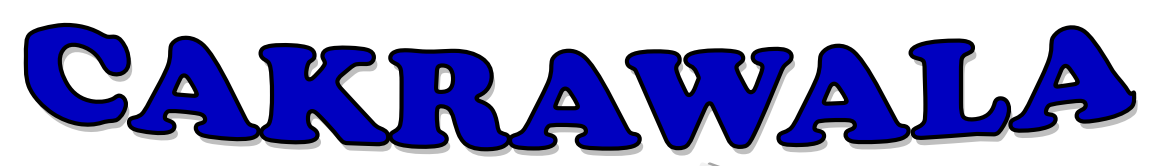

\section{Management Business Journal [CM:-BJ] Volume 1 Nomor 1 Tahun 2018}

dimilikinya, mulai dari makanan, camilan, kerajinan hingga produk kuliner tradisional khas dari masing-masing desa tersebut.

Berdasarkan pada kondisi di yang terjadi dilapangan, diperoleh temuan bahwa ada salah satu kesenian tradisional khas daerah yaitu sampyongan ujung yang Page |-17sudah mulai berkurang unsur nilai tradisionalnya, dikarenakan beberapa unsur pendukung dalam hal ini pakaian tradisional yang biasa digunakan pada kegiatan tarian sampyongan ujung sudah digantikan dengan pakaian modern yang lebih nyaman misalnya celana dan kaos oleh para penari, sedangkan untuk musik tradisional yang digunakan juga sudah mulai bergeser bukan hanya musik etnik yang biasanya digunakan untuk menari melainkan sudah berganti dengan musik dnagdut atau musik yang sedang tren saat ini. Kondisi semacam ini hendaknya perlu mendapatkan perhatian tersendiri karena Event Candipuro Culture Festival, merupakan rangkaian kegiatan yang berjalan sekaligus, dimana satu dengan yang lain saling melengkapi, sehingga unsur keaslian dan keotentikan budaya wajib untuk tetap dipertahankan dan dijaga kelestariannya.

Adanya pergeseran budaya menjadi sebuah indikasi dimana fungsi budaya sebagai nilai luhur bangsa sudah mulai perlu ditingkatkan lagi, akulturasi budaya bisa menjadi hal yang positif sepanjang makna filosofi dari budaya tersebut tidak hilang atau berubah makna.

\section{KESIMPULAN}

Berdasarkan hasil dan pembahasan yang dilakukan, maka kesimpulan dalam penelitian ini adalah strategi promosi pariwisata yang dilakukan dalam mempromosikan Event Candipuro Culture Festival, sudah berjalan dengan cukup baik, pemanfaatan media cetak, elektronik dan media online cukup mampu menarik minat wisatawan berkunjung ke event tersebut. Penggunaan media iklan dan publisitas dengan beragam media dimaksudkan agar Event Candipuro Culture Festival bisa lebih dikenal secara luas oleh masyarakat dan wisatawan, sekaligus 


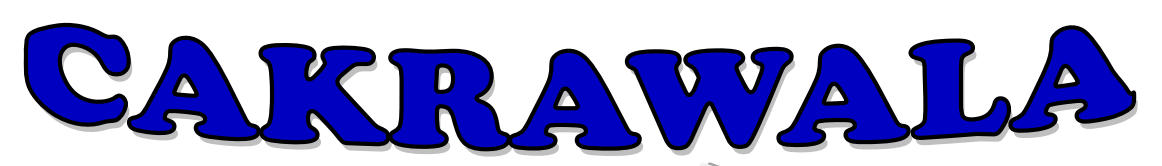

\section{Management Business Journal [CM:-BJ] Volume 1 Nomor 1 Tahun 2018}

akan dijadikan agenda rutin tahunan untuk meingkatkan pariwisata di daerah tersebut.

Sedangkan atraksi budaya yang ditampilkan pada Event Candipuro Culture Festival sebagian besar sudah berbasis budaya dan kearifan lokal dari masyarakat Page | - 18 setempat, yang berasal dari nilai tradisi yang dijalankan secara turun temurun dan masih tetap dipertahankan hingga saat ini, misalnya kegiatan grebeg suro di Desa Sumbermujur dan acara ruwatan air di Pemandian Tirtosari View Desa Penanggal. Dari keberagaman budaya, ditemukan sudah mulai mengalami pergeseran seiring modernisasi dan perkembangan zaman salah satunya pada kesenian tari sampyongan ujung, sehingga unsur tradisional sudah tergantikan dengan modernitas, walaupun masih dengan tujuan yang sama yaitu bentuk pelestarian budaya daerah. Sehingga diperlukan kerja sama yang baik dan tujuan yang sama agar seni tradisi bisa tetap dipertankan dan dijaga keasliannya, agar nilai tradisi bisa tetap lestari. Jika dibuat modifikasi hendaknya tidak terlalu menyimpang drai konteks awal kesenian tersebut, sehingga identitas budaya yang ditampilkan tidak hilang, terganti dengan modernitas sekarang.

\section{REKOMENDASI}

Keterbatasan penelitian adalah bidang kajian penelitian terbatas pada ruang lingkup wisata budaya saja, sehingga disarankan bagi penelitian selanjutnya untuk bisa mengkaji kegiatan promosi wisata dari jenis wisata yang lain, misalnya wisata alam, wisata minat khusus atau industri kreatif, mengingat wisata memiliki multi efek kepada bidang yang lain, sehingga lingkup yang dikaji menjadi lebih luas. Rekomendasi kegiatan penelitian yang dilakukan bagi pemerintah selaku pemimpin tertinggi dari suatu daerah, diharapkan agar hasil penelitian yang dilakukan bisa dijadikan bahan rujukan, bahan pembanding untuk mengetahui gambaran secara spesifik kondisi pariwisata khususnya wisata budaya, sekaligus dapat dijadikan 


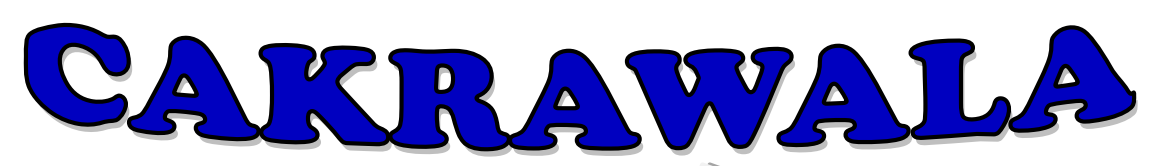

\section{Management Business Journal [C:M:B.J] Volume 1 Nomor 1 Tahun 2018}

bahan pertimbangan dalam pengambilan regulasi/kebijakan untuk pengembangan potensi pariwisata daerah.

Sasaran penelitian yang dilakukan terkait dengan bidang manajemen khususnya pemasaran jasa pariwisata, sehingga ke depannya disarankan agar Page |-19bidang kajian bisa menyangkut multi bidang yang relevan di dalamnya : misalnya manajemen Sumber Daya Manusia dan Kewirausahaan

\section{DAFTAR REFERENSI}

Bungin, Burhan. 2007. Penelitian Kualitatif, Ekonomi Kebijakan Publik dan Ilmu Sosial Lainnya. Jakarta : Kencana

Fadil, Zaki dan Utama, Priyo. 2015. Teknik Marketing Itu Mudah. Yogyakarta: Second Hope

Tjiptono, Fandi. 2002. Strategi Pemasaran. Erlangga : Jakarta

Malau, Harman. 2017. Manajemen Pemasaran. Teori dan Aplikasi Pemasaran Era Tradisional Sampai Era Modernisasi Global. Alfabeta : Bandung

Mia Rachmayanti dan Nofharina. 2018. Analisis Strategi Promosi dalam Pengembangan Pariwisata (Studi Kasus pada Pariwisata Kabupaten Purwakarta) . e-Proceeding of Management : Vol.5, No.1 Maret 2018 | Page 1259. ISSN : 2355-9357

Rai Utama, Gusti Bagus. 2017. Pemasaran Pariwisata. Andi : Yogyakarta

Setyaningrum Ari, Udaya Jusuf, dkk. 2015. Prinsip-Prinsip Pemasaran. Andi : Yogyakarta

Sutopo, H.B. 2002. Metodologi Penelitian Kualitatif, Dasar Teori dan Terapannya dalam Penelitian. Sebelas Maret Univercity Press : Surakarta.

Suryadana Liga M, Octavia Vanny. 2015. Pengantar Pemasaran Pariwisata. Alfabeta : Bandung

UU No. 10 tahun 2009 : Kepariwisataan

Undang-Undang No.6 Tahun 2014 : Desa 


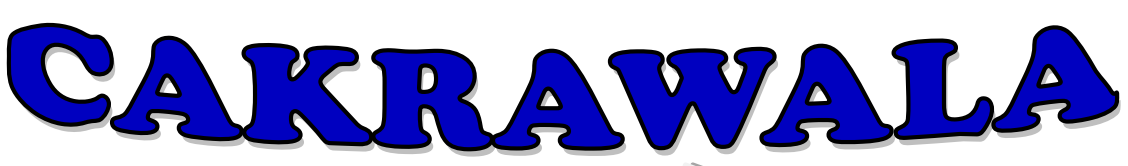

Management Business Journal [C:M-B:] Volume 1 Nomor 1 Tahun 2018

Yugih Setyanto, Septia Winduwati. 2017. Diseminasi Informasi Terkait Pariwisata Berwawasan Lingkungan dan Budaya Guna Meningkatkan Daya Tarik Wisatawan (Studi pada Dinas Pariwisata Provinsi Nusa Tenggara Barat). Jurnal Komunikasi. ISSN 2085-1979, EISSN 25282727 Vol. 9, No. 2, Desember 2017, Hal $164-175$. 